\title{
Peroxynitrite dominates sodium nitroprusside-induced apoptosis in human hepatocellular carcinoma cells
}

\author{
Ying-Yao Quan ${ }^{1}$, Yu-Hong Liu ${ }^{1}$, Chun-Mei Lin ${ }^{1}$, Xiao-Ping Wang ${ }^{1}$, Tong-Sheng Chen ${ }^{2}$ \\ ${ }^{1}$ Department of Pain Management, The First Affiliated Hospital of Jinan University, Guangzhou, China \\ ${ }^{2}$ MOE Key Laboratory of Laser Life Science and College of Life Science, South China Normal University, Guangzhou, China \\ Correspondence to: Xiao-Ping Wang, email: txp2938@jnu.edu.cn
}

Keywords: apoptosis, HepG2 cells, nitric oxide, peroxynitrite, sodium nitroprusside

Received: December 20, 2016

Accepted: March 03, 2017

Published: March 13, 2017

Copyright: Quan et al. This is an open-access article distributed under the terms of the Creative Commons Attribution License (CC-BY), which permits unrestricted use, distribution, and reproduction in any medium, provided the original author and source are credited.

\section{ABSTRACT}

This study aims to explore which radicals dominate sodium nitroprusside (SNP)-induced cytotoxicity in human hepatocellular carcinoma (HCC) cells (HepG2 and Hep3B). Exposure of SNP to cell medium produced abundant nitric oxide (NO), superoxide anion $\left(\mathrm{O}_{2}^{--}\right)$, hydrogen peroxide $\left(\mathrm{H}_{2} \mathrm{O}_{2}\right)$ and iron ions. SNP potently induced caspases activation, mitochondrial membrane permeabilization and apoptosis in HCC cells. In Hep3B cells, pretreatment with NO scavenger (PTIO) did not prevent SNPinduced cytotoxicity. However, in HepG2 cells, SNP-induced cytotoxicity was prevented significantly by pretreatment with PTIO and $\mathrm{O}_{2}{ }^{--}$scavenger, and especially was almost completely blocked by pretreatment with FeTPPS (peroxynitrite scavenger). In contrast, although $\mathrm{H}_{2} \mathrm{O}_{2}$ scavenger potently scavenged SNP-induced $\mathrm{H}_{2} \mathrm{O}_{2}$ production, it did not prevent SNP-induced cytotoxicity in HepG2 cells. In addition, pretreatment with DFO (iron ions chelator) and iron-saturated DFO respectively completely prevented SNP-induced cytotoxicity in HepG2 cells. Collectively, peroxynitrite from the reaction between $\mathrm{NO}$ and $\mathrm{O}_{2}{ }^{\circ-}$ elicited from SNP dominates the SNP-induced apoptosis of HepG2 cells, in which both iron ions and $\mathrm{H}_{2} \mathrm{O}_{2}$ are not involved.

\section{INTRODUCTION}

Sodium nitroprusside (SNP) is a potent hypotensive agent widely used for treating hypertension-emergencies during surgery and improving heart function after infarction [1]. SNP exposed to light or reducing condition rapidly releases nitric oxide (NO) that $[2,3]$ can directly relax vascular smooth muscle cells $[4,5]$. In addition to the vasorelaxant effect, NO has been demonstrated to be involved in many physiopathological responses, including platelet aggregation, respiration, cell migration, immune response and apoptosis [5-9]. It was reported that overexpression of gene-encoded NO synthase 2/3 (NOS2/3) potently increased the expressions of $\mathrm{p} 53, \mathrm{CD} 95$ and Rho kinase proteins [10,11]. Excessive NO elicited from NO donor (GSNO, SNAP, or NONOate) increased the expression and activation level of proapoptotic Bax protein [12] and caspases [13, 14], and the loss of mitochondrial membrane potential [14]. Interaction of NO with superoxide anions $\left(\mathrm{O}_{2}{ }^{-}\right)$produces peroxynitrite $\left(\mathrm{ONOO}^{-}\right)$[15], a much more toxic oxidant than $\mathrm{NO}$, that directly attacks DNA, triggers lipid peroxidation, dissipates mitochondrial membrane potential, and inactivates the complexes I, II, III and V of respiratory chain $[16,17]$. $\mathrm{ONOO}^{-}$can also promote cell death via triggering both caspase-dependent (e.g., cytochrome c, APAF-1, Smac) and caspase-independent (especially apoptosis-inducing factor) apoptotic signal pathways [18].

NO elicited from SNP is generally considered to be the key mediator responsible for the toxicological effects of SNP [19-22]. Based on the findings that SNP induced exogenous NO generation and apoptosis in chondrocytes, Blanco for the first time concluded that NO released from SNP dominated SNP-induced chondrocyte apoptosis [19]. This notion was widely adopted to study the molecular mechanism of SNP-induced apoptosis in various cell lines [20-22]. However, we and other research groups found that reactive oxygen species (ROS), the by-product of SNP independent of NO, mediated SNP-induced cytotoxicity in various kinds of cells [23-29]. Our recent studies firmly demonstrated that hydroxyl radicals $\left({ }^{\circ} \mathrm{OH}\right)$ from the Fenton reaction between iron ions and hydrogen peroxide $\left(\mathrm{H}_{2} \mathrm{O}_{2}\right)$ dominated the SNP-induced NOindependent chondrocytes apoptosis though SNP induced 
NO production [23]. Based on the potent inhibitory effect of uric acid, an $\mathrm{ONOO}^{-}$scavenger, on the cytotoxicity of SNP in mouse macrophage-like RAW264.7 cells some researchers speculated that $\mathrm{ONOO}^{-}$might play a key role in SNP-induced cytotoxicity [30, 31].

This study is designed to explore what radicals dominate SNP-induced apoptosis in human hepatocellular carcinoma (HepG2 and Hep3B) cells. In Hep3B cells, pretreatment with NO scavenger (PTIO) did not prevented SNP-induced cytotoxicity. However, pretreatment with PTIO (NO scavenger), SOD $\left(\mathrm{O}_{2}{ }^{\cdot-}\right.$ scavenger) and FeTPPS $\left(\mathrm{ONOO}^{-}\right.$scavenger) respectively markedly prevented SNP-induced cytotoxicity and generations of $\mathrm{NO}$ and $\mathrm{O}_{2}{ }^{--}$as well as $\mathrm{ONOO}^{-}$. Although CAT $\left(\mathrm{H}_{2} \mathrm{O}_{2}\right.$ scavenger $)$ significantly prevented SNP-induced hydrogen peroxide $\left(\mathrm{H}_{2} \mathrm{O}_{2}\right)$, it did not prevent SNP-induced cytotoxicity. Moreover, both DFO (iron ions chelator) and ironsaturated DFO exhibited superior inhibitory effects on SNP-induced $\mathrm{ONOO}^{-}$generation and apoptosis over PTIO and SOD. These findings demonstrate that $\mathrm{ONOO}^{-}$ from the reaction between $\mathrm{NO}$ and $\mathrm{O}_{2}{ }^{--}$dominates SNPinduced apoptosis independent of both iron ions and $\mathrm{H}_{2} \mathrm{O}_{2}$ in HepG2 cells.

\section{RESULTS}

\section{SNP induces cytotoxicity of $\mathrm{HCC}$ cells}

CCK-8 assay showed that exposure of HepG2 cells to different concentration $(0-1.5 \mathrm{mM})$ of SNP for $24 \mathrm{~h}$ induced a dose-dependent cytotoxicity (Figure 1A), and exposure of cells to $1.25 \mathrm{mM}$ of SNP for different times $(0-48 \mathrm{~h})$ induced a time-dependent cytotoxicity (Figure 1B). 1.25 mM SNP was adopted in following experiments without indication in HepG2 cells. Similar experiments in Hep3B cells also showed that SNP induced dose-dependent cytotoxicity (Figure 1C) and time-dependent cytotoxicity (Figure 1D). $5 \mathrm{mM} \mathrm{SNP}$ was adopted in following experiments without indication in Hep3B cells.

\section{NO mediates SNP-induced cytotoxicity in HepG2 cells}

Exposure of SNP to cell medium containing fetal bovine serum for $1,8,16$ and $24 \mathrm{~h}$ respectively induced a time-dependent increase of the nitrite/nitrate content (Supplementary Figure 1A). We also used FCM analysis with DAF-FM DA staining to detect the intracellular NO level, and found that SNP treatment for $1 \mathrm{~h}$ induced a $36 \pm 6.2 \%$ of increase in intracellular NO level that reached to peak at $8 \mathrm{~h}$ after SNP treatment (Supplementary Figure 1B). Pretreatment with $25 \mu \mathrm{M}$ of PTIO, a NO scavenger, completely prevented the SNPinduced NO production (Supplementary Figure 1C) and potently inhibited SNP-induced cytotoxicity in HepG2 cells (Figure 2A), demonstrating the important role of $\mathrm{NO}$ in SNP-induced cytotoxicity in this cell line. In contrast, PTIO pretreatment did not prevent SNP-induced cytotoxicity in Hep3B cells (Figure 2A), demonstrating that NO was not participate in SNP-induced cytotoxicity of Hep3B cells. Our previous study has indicated that 24-h-photodegreaded SNP (SNPex) released NO moiety completely [23]. We here found that SNP induced much more cytotoxicity (Figure 2B) than SNPex in HepG2 cells, further confirming the key role of NO in SNP-induced apoptosis in this cell line. However, in Hep3B cells, SNPex induced the same cytotoxicity as SNP (Figure 2B), further demonstrating that NO did not participate in SNPinduced cytotoxicity in Hep3B cells. Collectively, NO mediates SNP-induced cytotoxicity in HepG2 cells.

Further experiments in Hep3B cells show that ROS instead of NO play a dominant role in SNP-induced apoptosis in this cell line (private data), which is similar to our recent report in chondrocytes [23]. Therefore, we here focus on exploring how SNP induces apoptosis in HepG2 cells.

\section{NO mediates SNP-induced apoptosis}

Flow cytometry (FCM) analysis with Annexin V-FITC/PI staining was used to assess the form of cell death induced by SNP. Supplementary Figure 2A shows a representative dot-plot showing a time-dependent increase in apoptotic cells (Q2 (PI positive and Annexin V-FITC positive) + Q4 (PI negative and Annexin V-FITC positive)) from $5.5 \%$ (control) to $9.9 \%, 19.7 \%, 49.8 \%$ and $60.2 \%$ after SNP treatment for 12, 18, 24 and 48 h, respectively, and statistical results from three independent experiments are shown in Figure 3A. In accordance with CCK-8 assay (Figure 2B), we here found that SNP induced much more apoptosis than SNPex (Figure 3B), further confirming the key role of NO in SNP-induced apoptosis in HepG2 cells. In addition, FCM analysis with Rho 123 staining showed that SNP induced a time-dependent decrease of mitochondrial membrane potential $(\Delta \Psi \mathrm{m})$ (Supplementary Figure $2 \mathrm{~B}$ and Figure $3 \mathrm{C}$ ), indicating the permeabilization of mitochondrial outer membrane. FCM analysis with FITC-VAD-FMK staining showed a significant increase of cells with activated caspases from $7.6 \%$ (Control) to $43.6 \%$ after SNP treatment (Supplementary Figure 2C), and statistical results from three independent experiments showed that SNP induced a remarkable caspases activation (Figure 3D), demonstrating that caspases were involved in SNP-induced apoptosis. Collectively, NO mediates SNP-induced apoptosis through caspase-dependent mitochondrial apoptosis pathway of HepG2 cells.

\section{$\mathrm{O}_{2}^{--}$instead of $\mathrm{H}_{2} \mathrm{O}_{2}$ mediates SNP-induced cytotoxicity of HepG2 cells}

FCM analysis with DHE staining showed that SNP treatment for $1 \mathrm{~h}$ resulted in a significant increase of 
intracellular $\mathrm{O}_{2}{ }^{--}$, and the $\mathrm{O}_{2}^{-}$level reached to a peak at $8 \mathrm{~h}$ after SNP treatment (Figure 4A). SNP also induced a timedependent increase in $\mathrm{H}_{2} \mathrm{O}_{2}$ level, and the concentration of $\mathrm{H}_{2} \mathrm{O}_{2}$ in cell medium increased from $0.5 \pm 0.7 \mu \mathrm{M} / \mathrm{L}$ (control) to $41.0 \pm 3.5 \mu \mathrm{M} / \mathrm{L}$ after SNP treatment for $24 \mathrm{~h}$ (Figure 4B). FCM analysis showed that pretreatment with $200 \mathrm{U} / \mathrm{mL}$ SOD $\left(\mathrm{O}_{2}{ }^{-}-\right.$scavenger $)$completely prevented the SNP-induced $\mathrm{O}_{2} \cdot-$ production (Figure $4 \mathrm{C}$ ), and also potently prevented SNP-induced cytotoxicity (Figure 4D), indicating the important role of $\mathrm{O}_{2}^{-{ }^{-}}$in the SNP-induced cytotoxicity. In contrast, pretreatment with $5000 \mathrm{U} / \mathrm{mL}$ CAT (an $\mathrm{H}_{2} \mathrm{O}_{2}$ scavenger) completely prevented SNPinduced $\mathrm{H}_{2} \mathrm{O}_{2}$ production (Figure $4 \mathrm{E}$ ), but did not show any inhibitory effect on SNP-induced cytotoxicity (Figure 4F), illustrating that $\mathrm{H}_{2} \mathrm{O}_{2}$ was not involved in SNP-induced cytotoxicity. These data demonstrated that $\mathrm{O}_{2}^{--}$instead of $\mathrm{H}_{2} \mathrm{O}_{2}$ played an important role in SNPinduced cytotoxicity.

\section{$\mathrm{ONOO}^{-}$dominates SNP-induced apoptosis}

It is well known that $\mathrm{NO}$ can react with $\mathrm{O}_{2}^{--}$to produce the highly reactive nitrogen species $\mathrm{ONOO}^{-}$ [15]. As expected, FCM analysis with DHR 123 staining showed that SNP treatment for $1 \mathrm{~h}$ potently induced abundant $\mathrm{ONOO}^{-}$generation (Figure 5A). In order to evaluate the effect of $\mathrm{ONOO}^{-}$on SNP- induced apoptosis, we assessed the effect of FeTPPS, an ONOOdecomposition catalysts $\left(\mathrm{ONOO}^{-}\right.$specific scavengers), on the cytotoxicity of SNP. Pretreatment with PTIO (NO scavenger) and SOD $\left(\mathrm{O}_{2}{ }^{--}\right.$scavenger) respectively significantly prevented SNP-induced $\mathrm{ONOO}^{-}$generation, indicating that the reaction of $\mathrm{NO}$ and $\mathrm{O}_{2}{ }^{--}$elicited from SNP produced $\mathrm{ONOO}^{-}$. Pretreatment with FeTPPS completely prevented SNP-induced $\mathrm{ONOO}^{-}$generation (Figure 5B). CCK-8 assay showed that pretreatment with $10 \mu \mathrm{M}$ FeTPPS potently antagonized SNP-induced cytotoxicity (Figure 5C), illustrating the key role of $\mathrm{ONOO}^{-}$in SNP-induced cytotoxicity. Similarly, FeTPPS pretreatment also potently antagonized SNP-induced apoptosis (Figure 5D), loss of $\Delta \Psi \mathrm{m}$ (Figure 5E) and caspases activation (Figure $5 \mathrm{~F}$ ), further confirming the dominant role of $\mathrm{ONOO}^{-}$in $\mathrm{SNP}$-induced apoptosis of HepG2 cells.

\section{$\mathrm{ONOO}^{-}$has more cytotoxicity than NO}

To further determine the role of $\mathrm{NO}$ and $\mathrm{ONOO}^{-}$in SNP-induced cytotoxicity, we assessed the cytotoxicity of both NOC-5 and SIN-1, two NO donors. It was reported that NOC-5 only released NO during its decomposition, while SIN-1 released both $\mathrm{NO}$ and $\mathrm{O}_{2}^{\cdot-}$, and thus for the continuous formation of $\mathrm{ONOO}^{-}[32,33]$. FCM analysis showed that both NOC-5 and SIN-1 potently induced NO production (Figure 6A), SIN-1 also potently induced $\mathrm{ONOO}^{-}$ production whereas NOC-5 did not induce $\mathrm{ONOO}^{-}$ generation (Figure 6B). Figure 6C shows the statistical results from three independent experiments on the relative increase of both $\mathrm{NO}$ and $\mathrm{ONOO}^{-}$productions induced by NOC-5 and SIN-1, respectively. Although SIN-1 induced less NO production than NOC-5
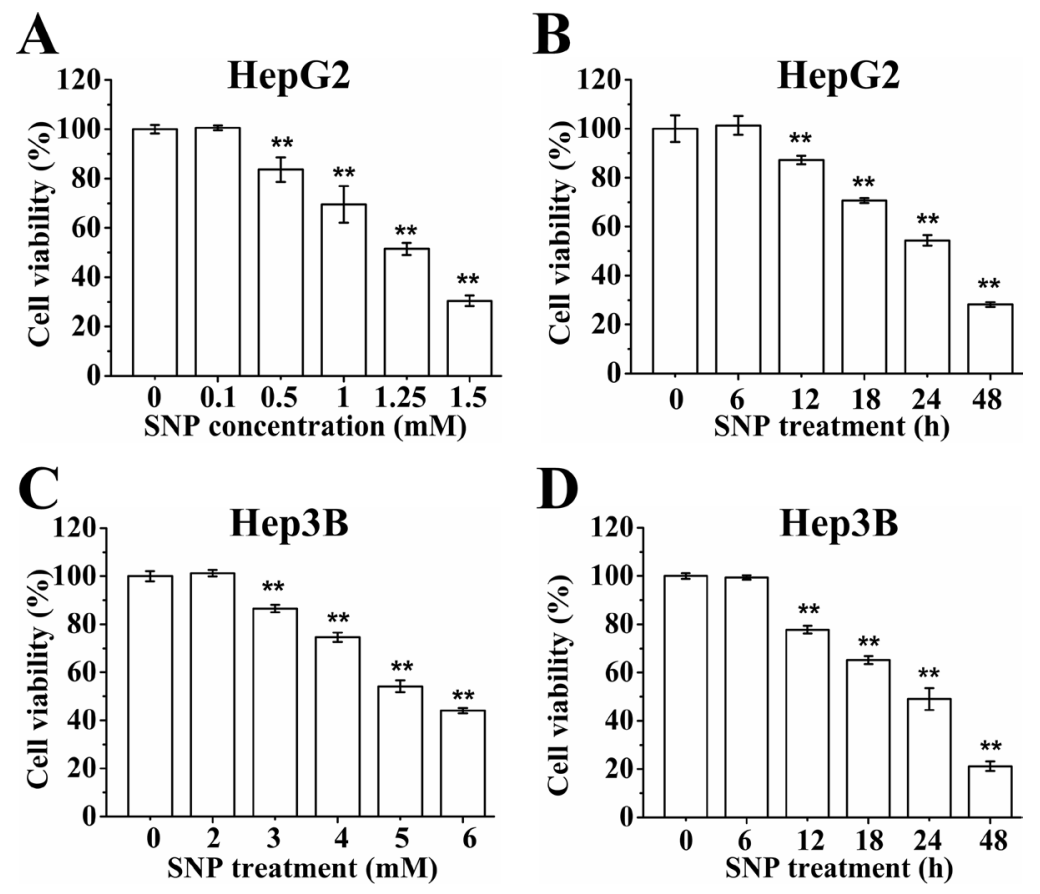

Figure 1: SNP induces cytotoxicity of HepG2 and Hep3B cells. (A and B) SNP induced dose- (A) and time-dependent (B) cytotoxicity of HepG2 cells. (C and D) SNP induced dose- (C) and time-dependent (D) cytotoxicity of Hep3B cells. Those results represent duplicates with three independent experiments. ${ }^{* *} P<0.01$ vs Control. 
(Figure 6D), SIN-1 had much more cytotoxicity than NOC-5 (Figure 6E), further supporting the notion that $\mathrm{HepG} 2$ cells were more sensitive to $\mathrm{ONOO}^{-}$than NO.

\section{Iron ions are not involved in SNP-induced cytotoxicity}

We firstly assessed the effect of DFO, an iron ion chelator, on the cytotoxicity of SNP, and found that DFO larger than $0.25 \mathrm{mM}$ almost completely prevented the SNP-induced cytotoxicity (Figure 7A). We next assessed the effects of $0.75 \mathrm{mM}$ DFO on SNP-induced generation of radicals including $\mathrm{NO}, \mathrm{O}_{2}^{--}$and $\mathrm{ONOO}^{-}$, and found that DFO completely inhibited SNP-induced $\mathrm{NO}, \mathrm{O}_{2}^{--}$and $\mathrm{ONOO}^{-}$generations (Figure $7 \mathrm{~B}$ ). These results demonstrated that DFO prevented SNP-induced cytotoxicity via scavenging $\mathrm{NO}, \mathrm{O}_{2}^{--}$and $\mathrm{ONOO}^{-}$.

SNP induced a time-dependent extracellular $\mathrm{Fe}^{2+}$ generation in cell medium (Figure 7C), and also significantly increased intracellular $\mathrm{Fe}^{2+}$ level after treatment for $16 \mathrm{~h}$ (Figure 7D). DFO completely chelated iron ions $(50-200 \mu \mathrm{M})$ in water, while iron-saturated DFO did not show any iron ions chelating effect (Figure 7E). However, iron-saturated DFO almost completely prevented SNP-
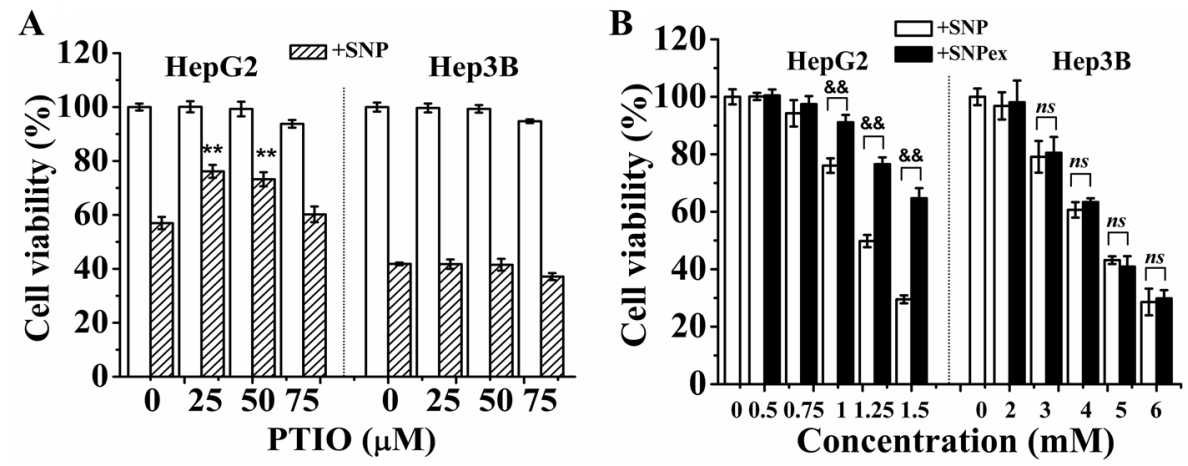

Figure 2: NO mediates SNP-induced cytotoxicity in HepG2 cells. (A) PTIO pretreatment inhibited SNP-induced cytotoxicity in HepG2 cells but not Hep3B cells. (B) SNP induced much more cytotoxicity than SNPex in HepG2 cells, and SNPex induced similar cytotoxicity as SNP in Hep3B cells. Those results represent duplicates with three independent experiments. $n s$ : no statistical significance. ${ }^{* *} P<0.01$ vs Control. \&\& $P<0.01$.
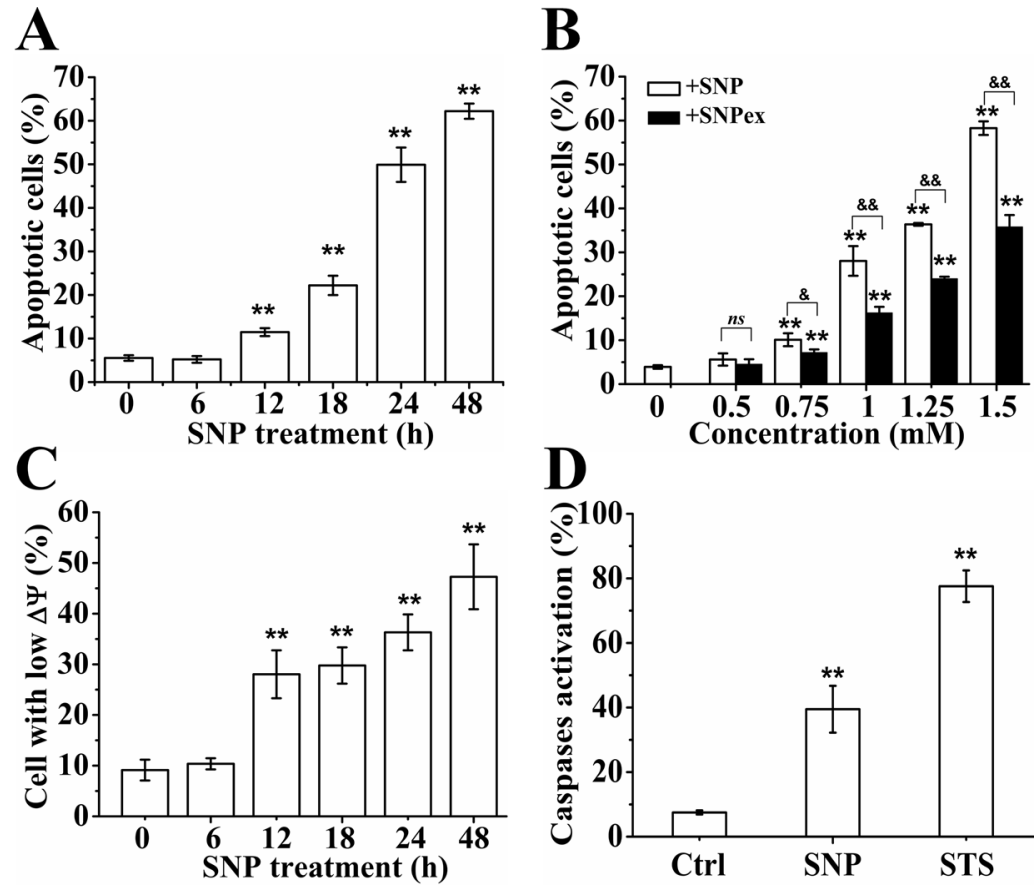

Figure 3: NO mediates SNP-induced apoptosis. (A) SNP induced time-dependent apoptosis in HepG2 cells. (B) SNP induced much more apoptosis than SNPex. (C) SNP induced time-dependent loss of $\Delta \Psi \mathrm{m}$. (D) SNP induced remarkable caspases activation. Those results represent duplicates with three independent experiments. $n s$ : no statistical significance. ${ }^{* *} P<0.01$ vs Control. \&\& $P<0.01$. 

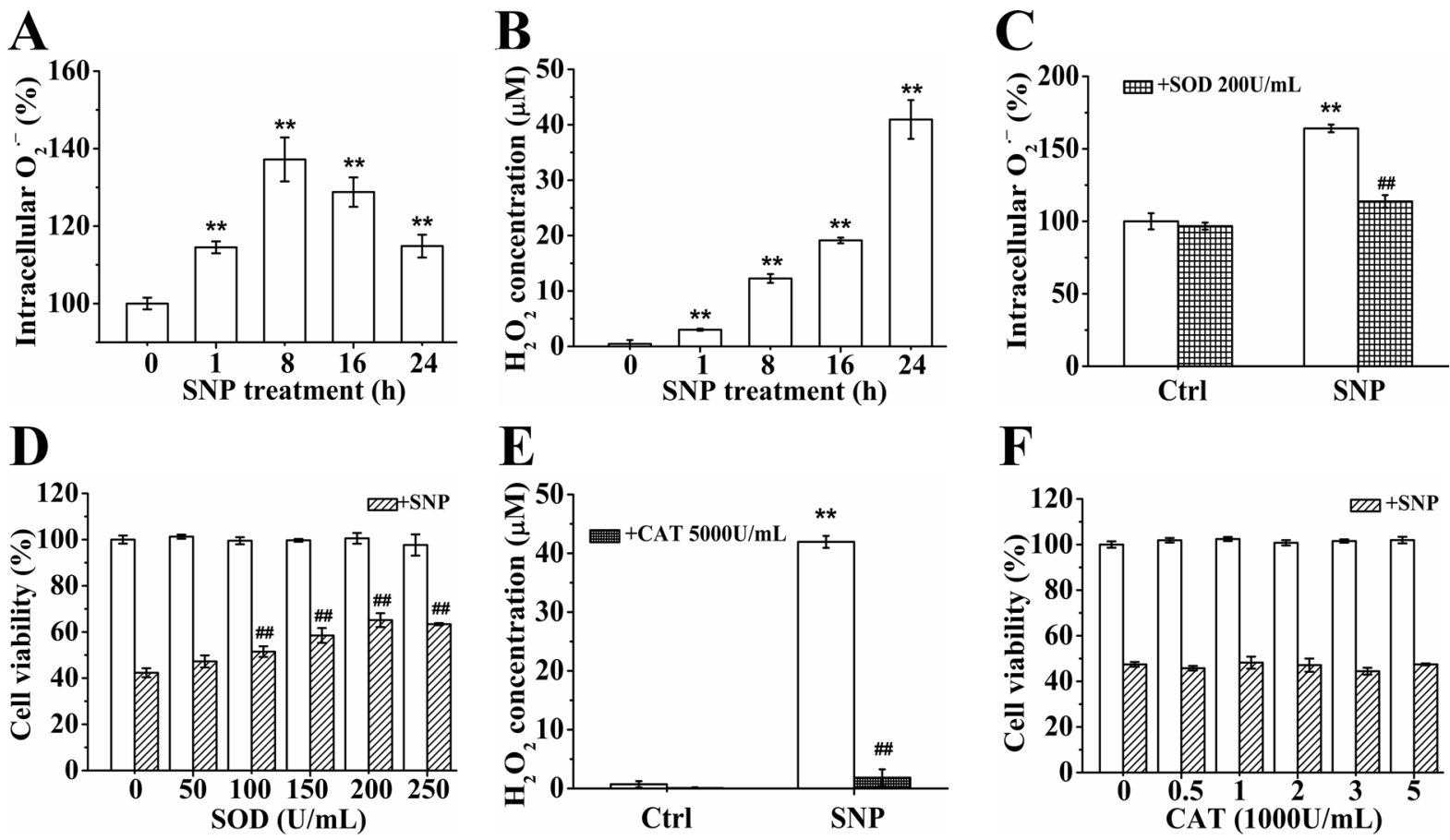

Figure 4: $\mathrm{O}_{2}^{--}$instead of $\mathrm{H}_{2} \mathrm{O}_{2}$ plays an important role in SNP-induced cytotoxicity. (A) SNP induced intracellular $\mathrm{O}_{2}^{-}$ generation. (B) SNP induced time-dependent $\mathrm{H} 2 \mathrm{O} 2$ generation. (C) SOD pretreatment completely inhibited SNP-induced $\mathrm{O}_{2}^{-}$- generation. (D) SOD pretreatment significantly prevented SNP-induced cytotoxicity. (E) CAT pretreatment completely inhibited SNP induced $\mathrm{H}_{2} \mathrm{O}_{2}$ generation. (F) CAT pretreatment did not prevent SNP-induced cytotoxicity. Those results represent duplicates with three independent experiments. ${ }^{* *} P<0.01$ vs Control. ${ }^{\#} P<0.01$ vs SNP.
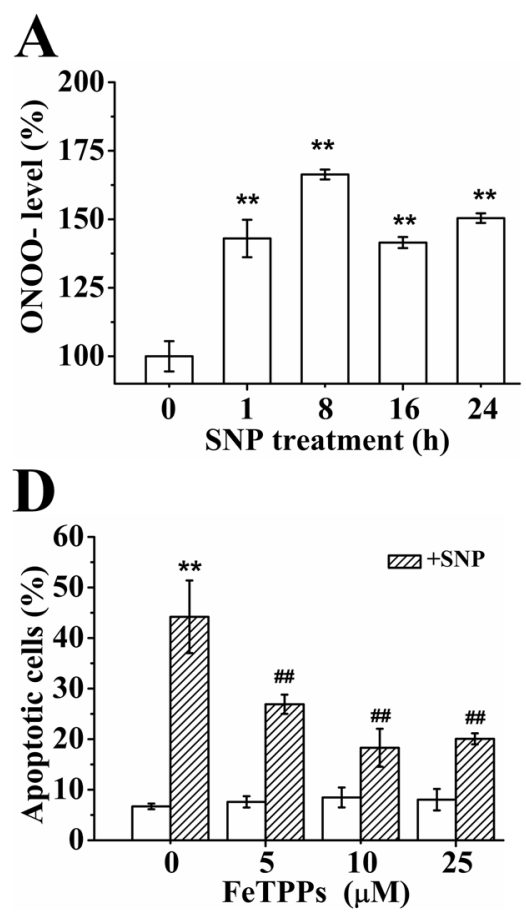

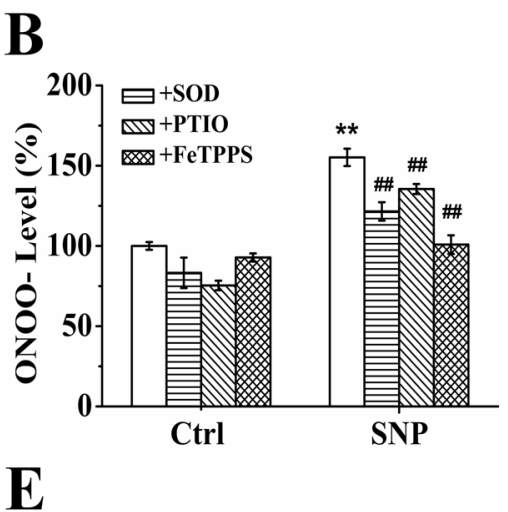

B

$\mathbf{E}$

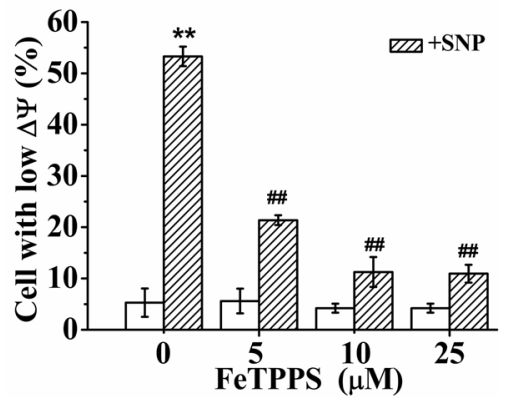

C
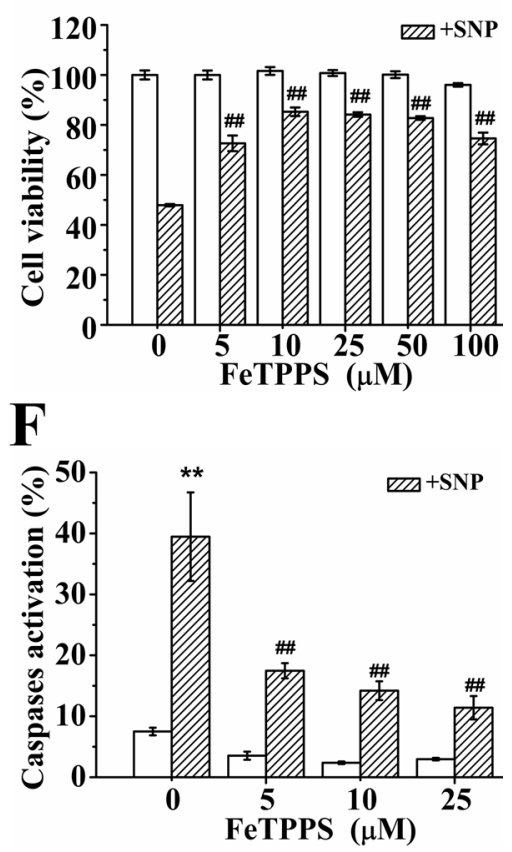

Figure 5: $\mathrm{ONOO}^{-}$dominates SNP-induced apoptosis. (A) SNP induced intracellular $\mathrm{ONOO}^{-}$generation. (B) Inhibitory effects of pretreatment with SOD, PTIO and FeTPPS respectively on SNP-induced $\mathrm{ONOO}^{-}$generation. (C-F) FeTPPS pretreatment potently inhibited SNP-induced cytotoxicity (C), apoptosis (D), decrease in $\Delta \Psi \mathrm{m}(\mathrm{E})$ and caspases activation (F). Those results represent duplicates with three independent experiments. ${ }^{* *} P<0.01$ vs Control. ${ }^{\#} P<0.01$ vs SNP. 
induced cytotoxicity (Figure 7F), indicating that iron ions did not participate in SNP-induced cytotoxicity.

\section{NAC promotes the cytotoxicity of SNP}

FCM analysis with DCFH-DA, a ROS probe, showed that SNP also potently induced ROS generation (Figure 8A). Although pretreatment with $1 \mathrm{mM}$ of NAC, a widely used ROS scavenger [24, 28], for $2 \mathrm{~h}$ could completely scavenged $500 \mu \mathrm{M}$ of $\mathrm{H}_{2} \mathrm{O}_{2}$, it did significantly enhance SNP-induced ROS generation (Figure $8 \mathrm{~B}$ ). Moreover, NAC pretreatment significantly enhanced SNP-induced nitrite/nitrate (Figure 8C) and $\mathrm{ONOO}^{-}$generations (Figure 8D). CCK-8 assay showed that pretreatment with NAC more than $1 \mathrm{mM}$ significantly enhanced the cytotoxicity of SNP. These data illustrated that NAC promoted the cytotoxicity of SNP by enhancing the SNP-induced $\mathrm{ONOO}^{-}$level.

\section{DISCUSSION}

This report for the first time demonstrates that $\mathrm{ONOO}^{-}$dominates SNP-induced apoptosis in HepG2 cells. Exposure of SNP to cell medium containing fetal bovine serum produced abundant $\mathrm{NO}, \mathrm{O}_{2}^{-}$, iron ions and $\mathrm{H}_{2} \mathrm{O}_{2}$. Reaction of $\mathrm{NO}$ and $\mathrm{O}_{2}^{--}$formed $\mathrm{ONOO}^{-}$with superior cytotoxicity over $\mathrm{NO}$ and $\mathrm{O}_{2}{ }^{--}$towards $\mathrm{HepG} 2$ cells. However, both iron ions and $\mathrm{H}_{2} \mathrm{O}_{2}$ did not participate in the SNP-induced cytotoxicity in this cell line. Interestingly, DFO exhibited a very excellent protective effect on the cytotoxicity of SNP via scavenging $\mathrm{NO}, \mathrm{O}_{2}^{-}$, and $\mathrm{ONOO}^{-}$.

Our observations that SNP induces abundant $\mathrm{ONOO}^{-}$production (Figure $5 \mathrm{~A}$ ) and FeTPPS almost completely antagonizes SNP-induced cytotoxicity (Figure 5C) illustrate the dominant role of $\mathrm{ONOO}^{-}$in SNP-induced apoptosis of HepG2 cells. NO has been considered to be a key factor to mediate SNP-induced cytotoxicity [19-22], which was further verified by our findings that PTIO obviously inhibited SNP-induced NO production and cytotoxicity (Supplementary Figure 1C and 2A) as well as SNPex induced less cytotoxicity than SNP (Figures 2B and 3B). However, many studies have demonstrated that the direct toxicity of $\mathrm{NO}$ is very modest $[27,33]$. Our recent study also showed that although SNP induced NO generation, ROS instead of NO mediated SNP-induced chondrocytes apoptosis [23]. Moreover, NOC-5 which induced more 50-fold than the SNPinduced $\mathrm{NO}$ production exhibited much lower cytotoxicity than that of SNP in chondrocytes [23]. Therefore, it is
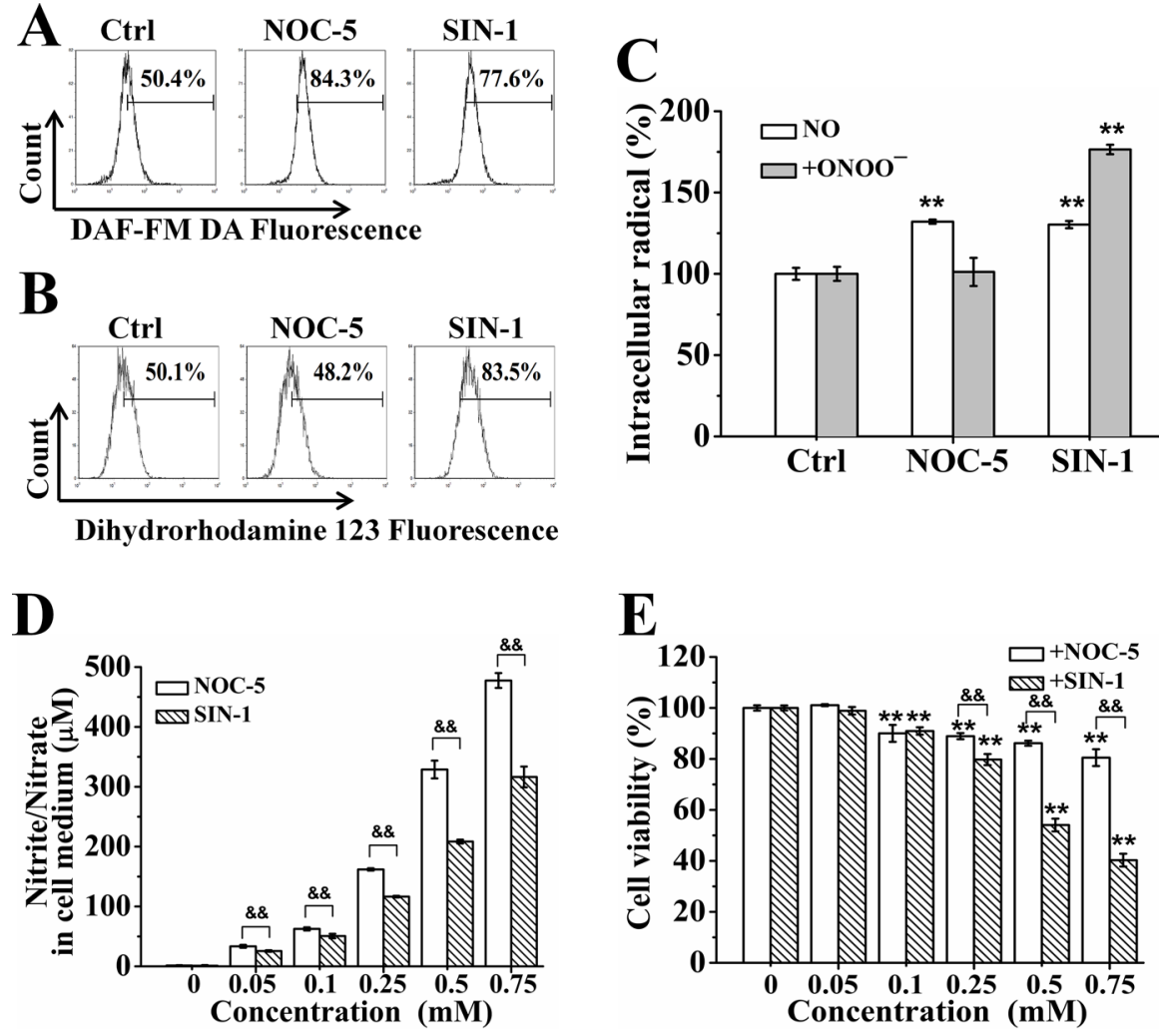

Figure 6: ONOO- has more cytotoxicity than NO. (A) Both NOC-5 and SIN-1 induced NO generation. (B) SIN-1 but not NOC induced $\mathrm{ONOO}^{-}$generation. (C) Statistical results on the relative increase of both $\mathrm{NO}$ and $\mathrm{ONOO}^{-}$production induced by NOC-5 and SIN-1, respectively. (D) NOC-5 induced more nitrite/nitrate generation than SIN-1. (E) SIN-1 induced much more cytotoxicity than NOC5. Those results represent duplicates with three independent experiments. NS: no statistical significance. ${ }^{* *} P<0.01$ vs Control. \&\& $P<0.01$. 
speculated that many potentially toxic effects of NO are more likely to be mediated by its oxidation products rather than NO itself [18].

Although $\mathrm{O}_{2}{ }^{--}$, the product of a one-electron reduction of oxygen, is generally poorly reactive and can only attack a few molecules [34], the fact that SOD pretreatment obviously inhibits SNP-induced cytotoxicity (Figure 4C) demonstrates the important role of $\mathrm{O}_{2}^{-{ }^{-}}$in $\mathrm{SNP}$-induced cytotoxicity in HepG2 cells. NO can react with $\mathrm{O}_{2}^{--}$to produce $\mathrm{ONOO}^{-}$with a reaction rate larger than $6.7 \times 10^{9} \mathrm{M}^{-1} \bullet \mathrm{s}^{-1}$, so that nearly every collision between $\mathrm{O}_{2}{ }^{--}$and $\mathrm{NO}$ results in the irreversible formation of $\mathrm{ONOO}^{-}[35,36]$, and a 10 -fold increase in $\mathrm{O}_{2}{ }^{--}$and NO will increase 100-fold of $\mathrm{ONOO}^{-}$formation [18, 37]. Based on the facts that SNP induces $\mathrm{NO}, \mathrm{O}_{2}{ }^{--}$and $\mathrm{ONOO}^{-}$ generation (Supplementary Figure 1A, Figures 4A and 5A) and PTIO/SOD modestly but FeTPPS almost completely inhibit SNP-induced $\mathrm{ONOO}^{-}$generation (Figure 5B) and cytotoxicity (Figures 2A, 4D and 5C), it is reasonable to consider that SNP firstly releases $\mathrm{NO}$ and $\mathrm{O}_{2}{ }^{-}$, and then rapidly forms $\mathrm{ONOO}^{-}$to dominate $\mathrm{SNP}$-induced apoptosis in HepG2 cells.

Moreover, although SOD or PTIO pretreatment completely prevented the SNP-induced $\mathrm{O}_{2}{ }^{--}$or $\mathrm{NO}$ production (Figure 4C and Supplementary Figure 1A), either PTIO or SOD does not completely antagonized SNP-induced cytotoxicity (Figures 2A and 4D) and $\mathrm{ONOO}^{-}$generation (Figure $5 \mathrm{~B}$ ). This may be ascribed to the different reaction rates between SOD/PTIO and $\mathrm{O}_{2}{ }^{--} / \mathrm{NO}$ as well as between $\mathrm{O}_{2}{ }^{--}$and NO. Consistent with our results, Goldstein and colleagues reported that the formation of $\mathrm{ONOO}^{-}$could not be efficiently inhibited by PTIO even under relatively low fluxes of $\mathrm{NO}$ and $\mathrm{O}_{2}{ }^{--}$and millimolar levels of PTIO [38]. Beckman and colleagues reported that the reaction rate of $\mathrm{O}_{2}{ }^{--}$with SOD to produce $\mathrm{H}_{2} \mathrm{O}_{2}$ was $\sim 2 \times 10^{9} \mathrm{M}^{-1} \bullet \mathrm{S}^{-1}$ [35], lower than the reaction

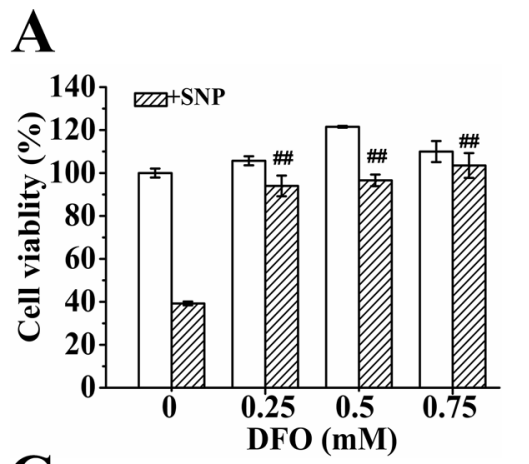

\section{B}
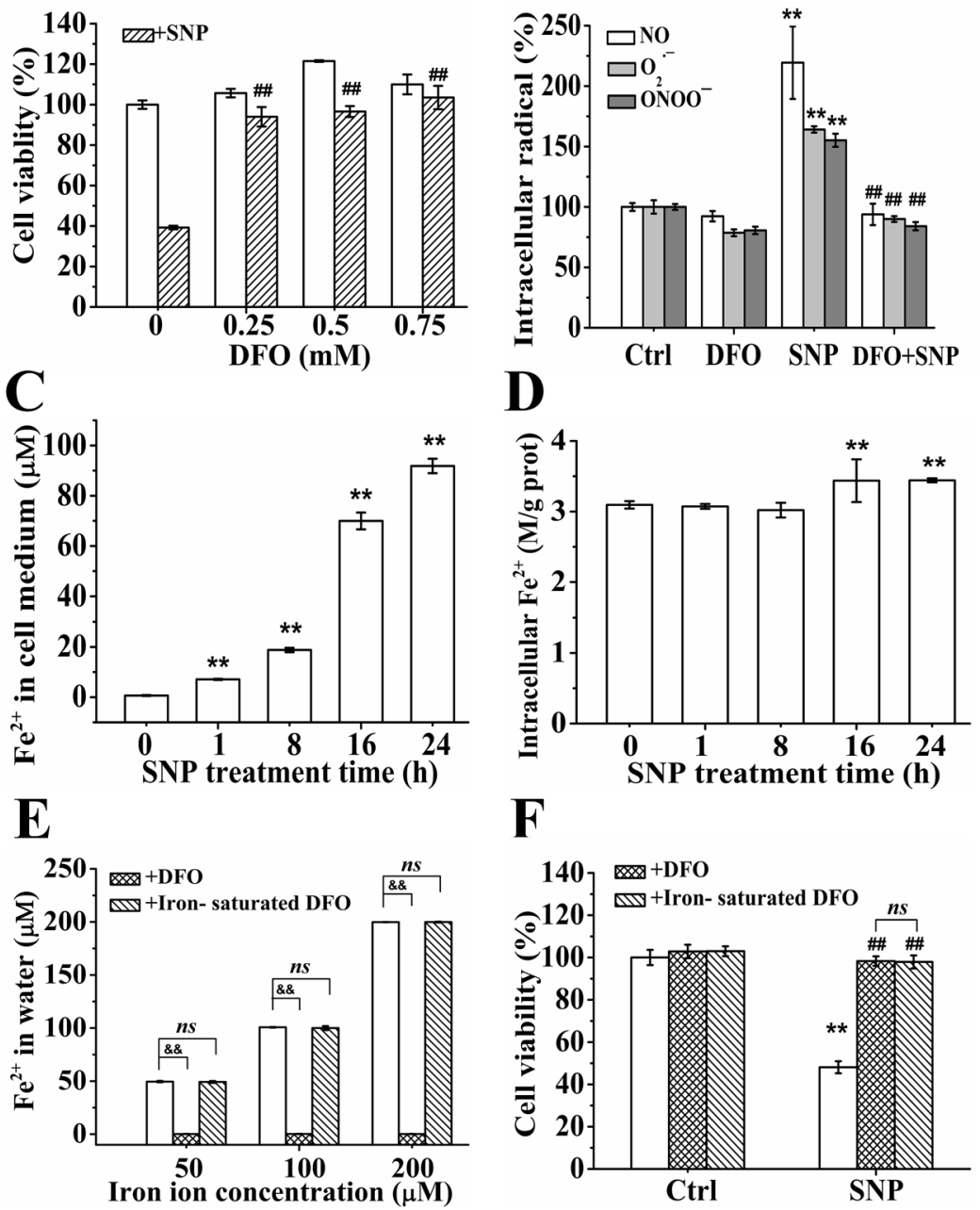

Figure 7: Iron ions are not involved in SNP-induced cytotoxicity. (A) DFO completely antagonized SNP-induced cytotoxicity. (B) DFO completely prevented SNP-induced $\mathrm{NO}, \mathrm{O}_{2}{ }^{-}$and $\mathrm{ONOO}^{-}$generations. (C) SNP induced time-dependent extracellular Fe2+ generation. (D) SNP treatment for more than $16 \mathrm{~h}$ induced statistically significant intracellular $\mathrm{Fe}^{2+}$ generation. (E) Iron ions chelating effect of DFO and iron-saturated DFO. (F) Both DFO and Iron-saturated DFO completely antagonized SNP-induced cytotoxicity. Those results represent duplicates with three independent experiments. NS: no statistical significance. ${ }^{* *} P<0.01$ vs Control. ${ }^{\# \#} P<0.01$ vs SNP. \&\& $P<0.01$. 
rate of $\mathrm{NO}$ and $\mathrm{O}_{2}^{--}$to produce $\mathrm{ONOO}^{-}[35,36]$, which may be the reason why SOD could only partially scavenge SNP-induced $\mathrm{ONOO}^{-}$(Figure 5B). Furthermore, $\mathrm{ONOO}^{-}$ is such a potent and versatile oxidant that can attack a wide range of biological targets [16] and induce apoptosis in various kinds of cells $[39,40]$. Based on the fact that FeTPPS completely scavenged SNP-induced ONOOgeneration (Figure 5B), it was reasonable that FeTPPS pretreatment almost completely antagonized SNP-induced cytotoxicity (Figure 5C-5F), exhibiting superior inhibitory effects on SNP-induced cytotoxicity over PTIO and SOD (Figures 5C, 2A and 4D).

In contrast to our recent findings that ${ }^{\circ} \mathrm{OH}$ from the Fenton reaction between iron ions and $\mathrm{H}_{2} \mathrm{O}_{2}$ released from SNP played a dominant role in SNP-induced chondrocytes apoptosis [23], we here found that both iron ions and $\mathrm{H}_{2} \mathrm{O}_{2}$ did not participate in the SNP-induced apoptosis in HepG2 cells (Figures 4F and 7F), though SNP did also induce $\mathrm{H}_{2} \mathrm{O}_{2}$ (Figure 4B) and iron ions generations (Figure 7C and 7D). $5000 \mathrm{U} / \mathrm{ml}$ CAT pretreatment completely prevented SNPinduced $\mathrm{H}_{2} \mathrm{O}_{2}$ production (Figure 4E), but did not show any inhibitory effect on SNP-induced cytotoxicity (Figure 4F). Similarly, iron-saturated DFO without any iron ions chelating effect (Figure 7E) also completely prevented SNP-induced cytotoxicity (Figure 7F). Based on the facts that SNP induced $\mathrm{H}_{2} \mathrm{O}_{2}$, iron ions, $\mathrm{NO}$ and $\mathrm{O}_{2}{ }^{--}$generations in both HepG2 cells (Supplementary Figure 1A, 1B, Figures 4A, 4B, 7C and 7D) and chondrocytes [23], we believed that SNP induced ${ }^{\circ} \mathrm{OH}$ and $\mathrm{ONOO}^{-}$generation in the two cell lines. However, in contrast to the dominant role of ${ }^{\circ} \mathrm{OH}$ for the cytotoxicity of SNP in chondrocytes [23], $\mathrm{ONOO}^{-}$instead of ${ }^{\circ} \mathrm{OH}$ played a dominant role in SNP-induced apoptosis in HepG2 cells (Figure 5). It is thus reasonable to infer that HepG2 cells are very sensitive to $\mathrm{ONOO}^{-}$instead of ${ }^{\circ} \mathrm{OH}$.
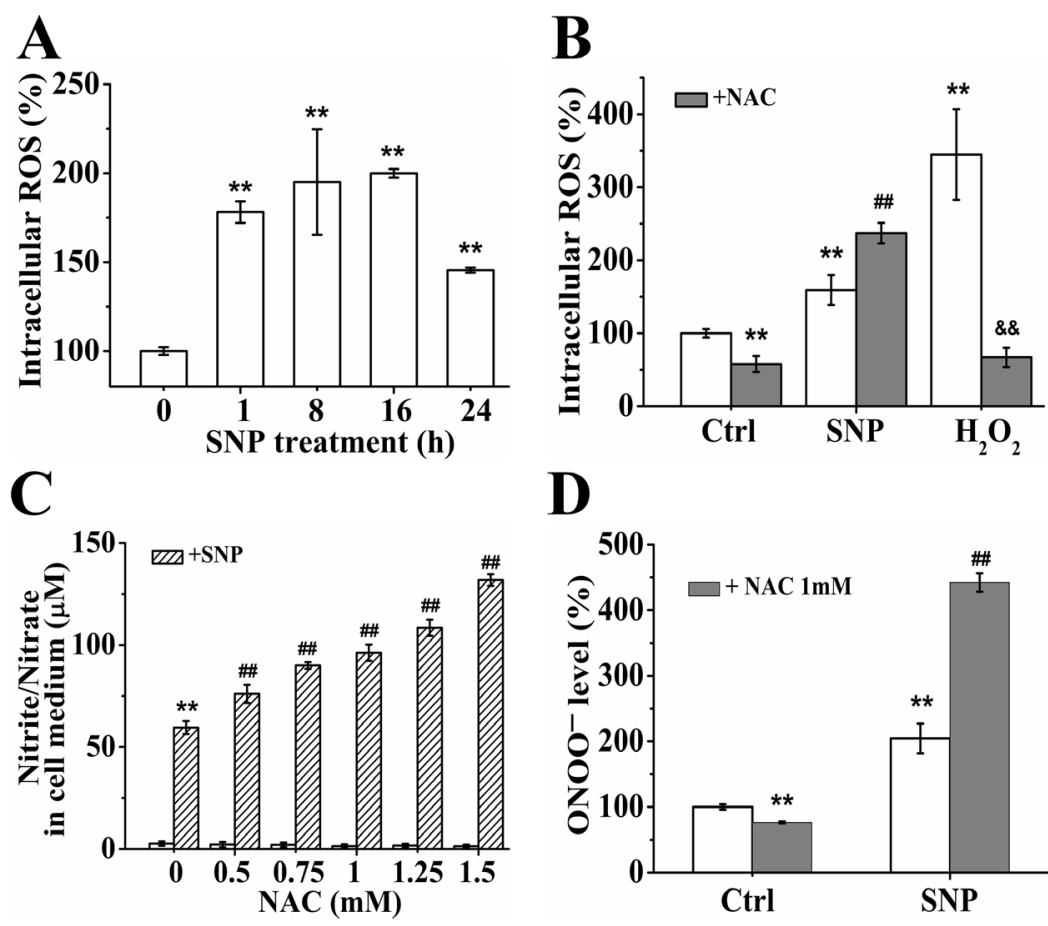

D
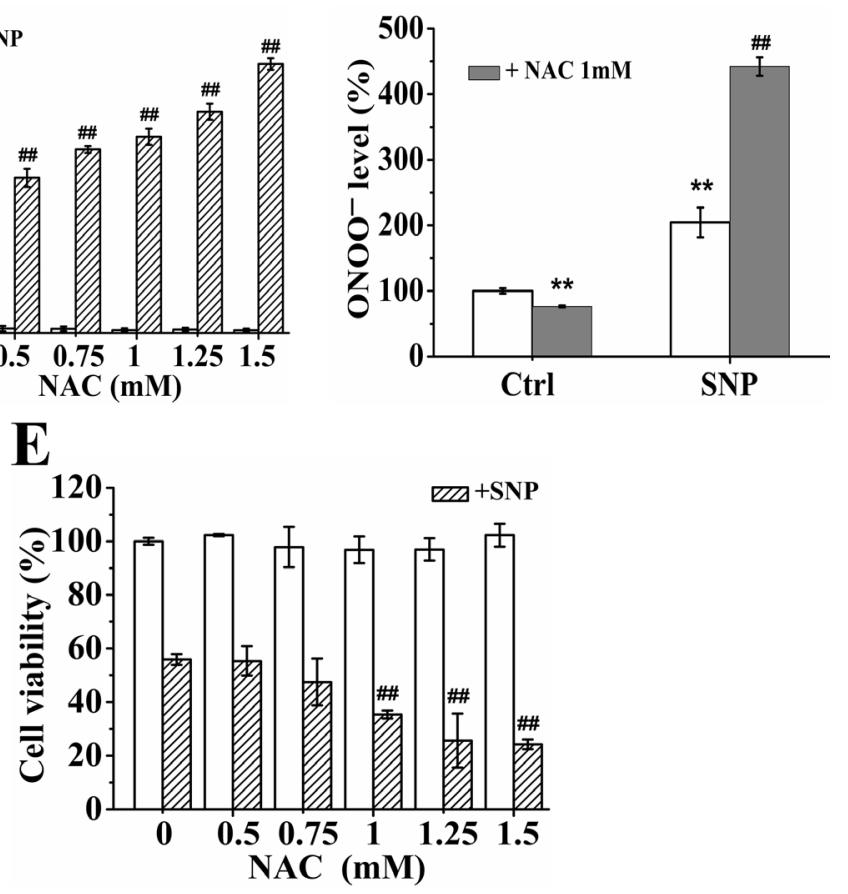

Figure 8: NAC promotes the cytotoxicity of SNP. (A) SNP induced intracellular ROS generation. (B) NAC pretreatment enhanced SNP-induced ROS generation. (C) NAC promoted SNP-induced nitrite/nitrate generation in dose-dependent manner. (D) NAC potently enhanced SNP-induced intracellular $\mathrm{ONOO}^{-}$generation. (E) NAC enhanced SNP-induced cytotoxicity. Those results represent duplicates with three independent experiments. ${ }^{* *} P<0.01$ vs Control. ${ }^{\#} P<0.01$ vs SNP. ${ }^{\$ \$} P<0.01$ vs $\mathrm{H}_{2} \mathrm{O}_{2}$. 
The maintenance of intracellular redox homeostasis depends on a complex web of antioxidant molecules. Tripeptide glutathione (GSH), a crucial component of cellular antioxidant defenses, protects cells against oxidative stress [41]. It was reported that GSH scavenged $\mathrm{O}_{2}{ }^{-}$and $\mathrm{H}_{2} \mathrm{O}_{2}$ with very slow rate constants of $10^{2} \sim 3 \times 10^{3}$ $\mathrm{M}^{-1} \cdot \mathrm{S}^{-1}$ [42-44] and $18 \sim 26 \mathrm{M}^{-1} \bullet \mathrm{S}^{-1}$ [43], respectively. However, GSH has a powerful ability to scavenge ${ }^{\circ} \mathrm{OH}$ with a rate constant of $8.8 \times 10^{9} \mathrm{M}^{-1} \bullet \mathrm{s}^{-1}$ [45]. Resistance of cell against oxidative stress is associated with high intracellular GSH levels [46-48]. It was reported that the GSH level of HepG2 cells was about 50 ng/mg protein [49], much higher than the $\sim 14 \mathrm{ng} / \mathrm{mg}$ protein in chondrocytes we recently measured [23]. Therefore, we here speculated that the high level of intracellular GSH in HepG2 cells could rapidly scavenge the $\mathrm{OH}$ from the Fenton reaction between $\mathrm{H}_{2} \mathrm{O}_{2}$ and iron ions released from SNP, which might be the reason why iron ions and $\mathrm{H}_{2} \mathrm{O}_{2}$ released from SNP were not involved in the SNP-induced apoptosis in HepG2 cells.

Peroxiredoxins (Prxs), a ubiquitous family of cysteine-dependent peroxidase enzymes, can reduce more than $90 \%$ of cellular peroxides and has been considered to be the only enzymes known to catalyze the reduction of $\mathrm{ONOO}^{-}$to nitrite [50]. Moreover, Prxs were considered to be the most efficient $\mathrm{ONOO}^{-}$scavengers [51]. It was reported that Prxs reacted with $\mathrm{ONOO}^{-}$with constants on the order of $\sim 10^{6} \times 10^{7} \mathrm{M}^{-1} \bullet \mathrm{s}^{-1}[52-54]$, much higher than the reaction constant $\left(1400 \mathrm{M}^{-1} \bullet \mathrm{s}^{-1}\right)$ between $\mathrm{GSH}$ and $\mathrm{ONOO}^{-}$ [54]. It is well recognized that the content of Prxs is celland tissue-specific [55]. The fact that $\mathrm{ONOO}^{-}$dominates the SNP-induced cytotoxicity (Figure 5) indicates that the endogenic Prxs of HepG2 cells are unable to effectively scavenge the SNP-induced ONOO-.

Our observation that iron-saturated DFO completely prevented SNP-induced cytotoxicity in HepG2 cells (Figure 7F) further confirms the notion that many physiological effects, including inhibiting $\mathrm{ONOO}^{-}$mediated oxidation, of DFO are independent of metal chelation $[56,57]$. Although iron ions were not involved in SNP-induced apoptosis in HepG2 cells (Figure 7E and $7 \mathrm{~F}$ ), DFO, an iron ions chelator, completely prevented SNP-induced cytotoxicity (Figure 7A). It was reported that DFO can directly scavenge $\mathrm{ONOO}^{-}$and $\mathrm{O}_{2}^{-{ }^{-}}[56,58]$, which was further confirmed by our findings that DFO completely scavenged $\mathrm{O}_{2}^{\cdot-}$ and $\mathrm{ONOO}^{-}$generations (Figure 7B) in HepG2 cells. . In addition, we here for the first time found that DFO could also completely inhibit SNP-induced NO (Figure 7B), strongly demonstrating the scavenging effect of DFO on NO. Moreover, we also assessed the effect of DFO on SNP-induced nitrites/ nitrates variation, and found that DFO did not prevent the decomposition of SNP (data not shown). Therefore, the complete protective effect of DFO on SNP-induced apoptosis in HepG2 cells is due to the complete scavenging action of DFO on the SNP-induced $\mathrm{NO}, \mathrm{O}_{2}{ }^{-}$ and $\mathrm{ONOO}^{-}$generations.
To our surprise, NAC, a widely used ROS scavenger, significantly enhanced the cytotoxicity of SNP in HepG2 cells (Figure 8E). Although NAC exhibited excellent role in inhibiting $\mathrm{H}_{2} \mathrm{O}_{2}$ (Figure $8 \mathrm{~B}$ ), it potently increased SNP-induced intracellular ROS/ $\mathrm{ONOO}^{-}$(Figure $8 \mathrm{~B}$ and 8D). Our results that NAC enhanced the SNP-induced an increase of the nitrites/nitrates concentration (Figure 8C) further confirmed the notion that some reducing agents such as thiols contributed the reductive biodegradation of SNP to release NO [3]. Similarly, Ottaviani and colleagues reported that NAC enhanced the cytotoxicity of SNP in fat body cells (IPLB-LdFB) [59]. Collectively, NAC promoted the decomposition of SNP to release NO and $\mathrm{O}_{2}{ }^{-}$, enhancing the formation of $\mathrm{ONOO}^{-}$, and thus enhancing the cytotoxicity of SNP in HepG2 cells.

In reality, we also assessed the role of $\mathrm{ONOO}^{-}$and -OH in SNP-induced apoptosis in Hep3B cells. PTIO did not prevented SNP-induced cytotoxicity (Figure 2A) and SNPex induced the same cytotoxicity as SNP (Figure 2B), which indicated that NO was not involved in SNP-induced cytotoxicity of Hep3B cells. In contrast to the dominant role of $\mathrm{ONOO}^{-}$in $\mathrm{SNP}$-induced apoptosis in HepG2 cells, 'OH instead of $\mathrm{ONOO}^{-}$dominated SNP-induced apoptosis in Hep3B cells (data not shown). We are currently focusing on exploring the roles of endogenic antioxidants such as GSH and Prxs towards SNP-induced oxidative and nitrative stress in various cell lines including Hep3B and HepG2 cell lines.

We summarize the metabolism products associated with the potent proapoptotic actions of SNP in HepG2 cells in Figure 9. After exposure to cell culture medium containing fetal bovine serum, SNP releases $\mathrm{NO}, \mathrm{O}_{2}{ }^{-}$, $\mathrm{H}_{2} \mathrm{O}_{2}$ and iron ions. Reaction of $\mathrm{NO}$ with $\mathrm{O}_{2}{ }^{--}$produces $\mathrm{ONOO}^{-}$to dominate SNP-induced apoptosis in which both iron ions and $\mathrm{H}_{2} \mathrm{O}_{2}$ are not involved. In addition, DFO exhibits a very excellent inhibitory effect on SNPinduced cytotoxicity by scavenging $\mathrm{NO}, \mathrm{O}_{2}{ }^{-}$and $\mathrm{ONOO}^{-}$. Sensibility of HepG2 cells to $\mathrm{ONOO}^{-}$instead of $\mathrm{H}_{2} \mathrm{O}_{2}$ and ${ }^{\circ} \mathrm{OH}$ may be due to the high intracellular GSH level. However, the precise biological mechanism by which $\mathrm{ONOO}^{-}$dominates SNP-induced apoptosis in HepG2 cells is unclear, and we are focusing on this issue by further exploring the roles of GSH and Prxs in the response of various kinds of cell lines to oxidative stress.

\section{MATERIALS AND METHODS}

\section{Materials}

SNP, dimethyl sulphoxide (DMSO), Carboxy-PTIO (PTIO), N-acetyl cysteine (NAC), 2', 7'-Dichlorofluorescin diacetate (DCFH-DA), Deferoxamine mesylate salt (DFO), catalase (CAT) and Rhodamine 123 (Rho 123) were from Sigma (St. Louis, USA). Fe(III) $5,10,15,20$-tetrakis(4-sulfonatophenyl) porphyrinato chloride (FeTPPS) and 2-(3,6-diamino-9H-xanthen-9-yl)- 
benzoic acid, methyl ester (DHR 123) were from Cayman (MI, USA). 3-(Aminopropyl)-1-hydroxy-3-isopropyl-2oxo-1-triazene (SIN-1) and 3-morpholinosydnonimine (NOC-5) were from Enzo Life Sciences Inc (New York, USA). Dulbecco's modified Eaglemedium (DMEM) was from Gibco (Carlsbad, California, USA). Fetal bovine serum (FBS) was from Sijiqing (Hangzhou, China). 3-Amino,4-aminomethyl-2',7'-difluorescein, diacetate (DAF-FM DA), RIPA lysis reagent, Dihydroethidium (DHE), superoxide dismutase (SOD) and Staurosporine (STS) were from Beyotime Institute Biotechnology (Jiangsu, China).

\section{Cell lines and cell culture}

HepG2 and Hep3B cells were purchased from the Experimental Animal Center, SUN YAT-SEN University (Guangzhou, China), and were cultured in DMEM supplemented with antibiotics $(100 \mathrm{U} / \mathrm{ml}$ penicillin and $100 \mathrm{U} / \mathrm{ml}$ streptomycin) at $37^{\circ} \mathrm{C}$ in humidified $5 \% \mathrm{CO}_{2}$.

\section{Treatments}

SNP powder was freshly dissolved in ultrapure water to obtain $100 \mathrm{mM}$ concentration SNP solution before experiment. Then, the SNP was diluted in culture medium and added to cells to obtain various concentrations. All SNP experiments were performed in dark. Exhausted SNP (SNPex) was obtained by leaving the solution of SNP under light exposure for $24 \mathrm{~h}$ at room temperature as described previously [23]. NOC-5 was freshly dissolved in $0.1 \mathrm{M} \mathrm{NaOH}$. SIN-1 was freshly dissolved in PBS solution. CAT and NAC were prepared just before the experiments by dissolving the powders in ultrapure water. FeTPPS, SOD and DFO were dissolved in ultrapure water as stock solution and stored at $-20^{\circ} \mathrm{C}$ in the dark. Iron-saturated DFO was made by dissolving equimolar amount of DFO and then ferric chloride in saline [60]. PTIO was dissolved in DMSO, and the final concentration of DMSO was less than $0.1 \%(\mathrm{v} / \mathrm{v})$ in experiment. HepG2 cells were pretreated with NAC or PTIO for $2 \mathrm{~h}$, and CAT, SOD, DFO, FeTPPS for $30 \mathrm{~min}$, and then co-treated with 1.25 mM SNP for $24 \mathrm{~h}$. HepG2 cells were exposed to NOC- 5 for $0.5 \mathrm{~h}, \mathrm{SIN}-1$ for $2 \mathrm{~h}$. For all cell experiments, before drugs treatment, cells were replaced with fresh medium.

\section{Cell viability and apoptosis assay}

Cell viability was detected by Cell Counting Kit-8 (CCK-8) assay (Dojindo, Kumamoto, Japan) as described previously [29]. HepG2 cells cultured in 96well plates $\left(1 \times 10^{4}\right.$ per well $)$ for $24 \mathrm{~h}$ were treated with different stimuli, viable cells were assessed by absorbance measurements at $450 \mathrm{~nm}$ using an auto microplate reader (infinite M200, Tecan, Austria). Hep3B cells cultured in 96-well plates $\left(1 \times 10^{4}\right.$ per well $)$ for $24 \mathrm{~h}$ were treated with different stimuli, viable cells were assessed by absorbance measurements at $450 \mathrm{~nm}$ using the microplate reader.

Cell apoptosis was quantified by flow cytometry (FCM) (FACSCCanto II, BD Biosciences) analysis with Annexin V-FITC/PI apoptosis detection kit (Bestbio, Shanghai, China) as described previously [29]. HepG2 cells cultured in 6 -well $\left(5 \times 10^{5}\right.$ per well $)$ plates for $24 \mathrm{~h}$ were treated with different stimuli, then the cells were collected and stained with $5 \mathrm{ml}$ of AnnexinV-FITC and $10 \mathrm{ml} \mathrm{PI}$ for $15 \mathrm{~min}$ at $4^{\circ} \mathrm{C}$ before FCM analysis. 10,000 events were recorded for each FCM analysis.

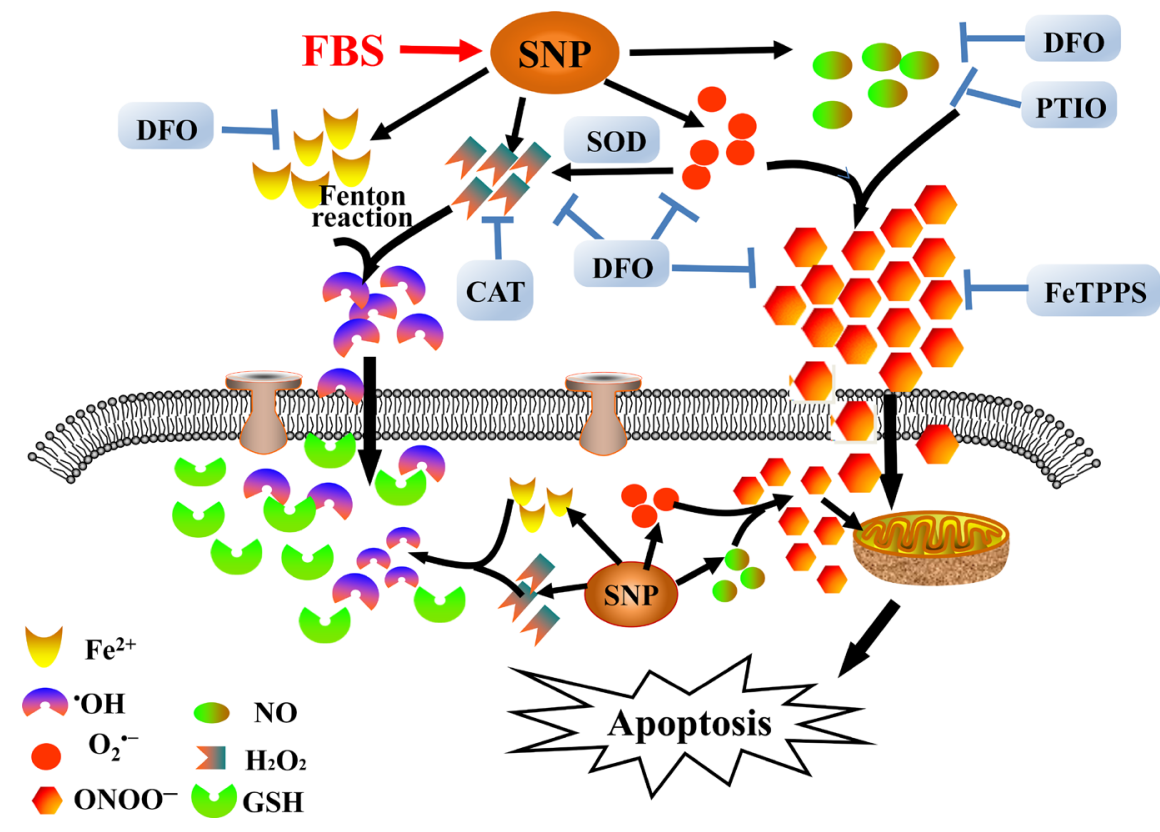

Figure 9: Schematic diagram showing decomposition of SNP and subsequent proapoptotic action in HepG2 cells. 


\section{Measurement of mitochondrial membrane potential $(\Delta \Psi \mathrm{m})$}

Loss of $\Delta \Psi \mathrm{m}$ was assessed by FCM analysis with Rho 123 staining as previously described [29]. Briefly, HepG2 cells cultured in 6-well plates for $24 \mathrm{~h}$ were treated with different stimuli, and were subsequently harvested and stained with $5 \mu \mathrm{M}$ Rho 123 at $37^{\circ} \mathrm{C}$ for $20 \mathrm{~min}$ in dark, then washed with PBS twice before FCM analysis. Results were expressed as the proportion of cells with low Rho 123 fluorescence indicating the loss of $\Delta \Psi \mathrm{m}$.

\section{Determination of caspases activation}

The CaspACE FITC-VAD-FMK In Situ Marker (Promega Corporation, WI, USA) was used to detect the activation of caspases according to the manufacture's protocol. The structure of the cell-permeable caspase inhibitor peptide VAD-FMK (Val-Ala-Asp-Phe-Met-Lys) conjugated to FITC allows delivery of the inhibitor into the cell, where it binds to activated caspase, serving as an in situ marker for apoptosis. HepG2 cells cultured in 6-well plates for $24 \mathrm{~h}$ were treated with different stimuli, and then the cells were collected and diluted in $0.5 \mathrm{ml}$ PBS. The cells were stained with $1 \mu$ of FITC-VAD-FMK $(5 \mathrm{mM})$ at $37^{\circ} \mathrm{C}$ for $20 \mathrm{~min}$ in dark, and then they were washed with PBS twice before FCM analysis.

\section{Measurement of nitrite and nitrate}

NO concentration was indirectly quantified by measuring its oxidation by-products nitrites and nitrates using the auto microplate reader just as described previously [23]. Cells cultured in 6-well plates for $24 \mathrm{~h}$ were treated with different stimuli, and then $50 \mu \mathrm{l}$ cell medium of each sample was collected and mixed with $50 \mu \mathrm{l}$ Griess reagents at room temperature for $10 \mathrm{~min}$ in 96-well plates. Absorbance at 540 $\mathrm{nm}$ was measured using the auto microplate reader.

\section{Measurement of intracellular ROS and NO}

DCFH-DA and DAF-FM DA are cell-permeable fluorescent probes. Intracellular ROS or NO level was quantified by using FCM analysis with DCFH-DA or DAF-FM DA staining just as described previously [29]. Cells cultured in 6-well plates for $24 \mathrm{~h}$ were treated with different stimuli, and then cells were collected and stained with $20 \mu \mathrm{M}$ DCFH-DA for 30 min or with $5 \mu \mathrm{M}$ DAF-FM DA for $20 \mathrm{~min}$ at $37^{\circ} \mathrm{C}$ in dark. After washing with PBS three times, the samples were analyzed by FCM.

\section{Measurement of superoxide anion $\left(\mathrm{O}_{2}^{-{ }^{-}}\right)$and Peroxynitrite $\left(\mathrm{ONOO}^{-}\right)$}

DHE and DHR 123 are cell-permeable fluorescent probes. Intracellular $\mathrm{O}_{2}^{-{ }^{-}}$or $\mathrm{ONOO}^{-}$level was quantified by using FCM analysis with DHE or DHR 123 staining. DHE, an $\mathrm{O}_{2}^{--}$sensitive probe, reacts with $\mathrm{O}_{2}^{--}$to form a diagnostic marker product (2-hydroxyethidium, 2-OH$\mathrm{E}+$ ). DHR 123 is oxidized by $\mathrm{ONOO}^{-}$to the highly fluorescent product rhodamine. Briefly, cells cultured in 6-well plates for $24 \mathrm{~h}$ were treated with different stimuli, then the cells were collected and stained with $10 \mu \mathrm{M}$ DHE for $30 \mathrm{~min}$ or with $10 \mu \mathrm{M}$ DHR 123 for $20 \mathrm{~min}$ at $37^{\circ} \mathrm{C}$ in the dark. After washing with PBS three times, the samples were analyzed by FCM.

\section{Measurement of $\mathrm{H}_{2} \mathrm{O}_{2}$}

$\mathrm{H}_{2} \mathrm{O}_{2}$ concentration was measured using the Amplite fluorimetric hydrogen peroxide assay kit (ATT Bioquest, Sunnyvale, CA) just as described previously [23]. Briefly, cells cultured in 6-well plates for $24 \mathrm{~h}$ were treated with different stimuli, then $50 \mu \mathrm{l}$ cell medium was collected and incubated with $50 \mu \mathrm{l}$ reaction mixtures provided by the kit for $30 \mathrm{~min}$ at room temperature. $\mathrm{H}_{2} \mathrm{O}_{2}$ level was detected at $570 \mathrm{~nm}$ in 96 -well plates by using the auto microplate reader.

\section{Determination of iron ions}

Iron ions concentration was determined using QuantiChrom ${ }^{\mathrm{TM}}$ Iron Assay Kit (BioAssay Systems, CA, USA) according to the manufacture's protocol. HepG2 cells cultured in 6-well plates were treated with different stimuli, and then cell medium and cell lysate were collected just as described previously [23]. Briefly, $50 \mu 1$ of cell medium or cell lysate was mixed with $200 \mu 1$ of reaction mixture provided by the kit and then incubated for $40 \mathrm{~min}$ at room temperature in 96-well plates. The optical density was measured at $590 \mathrm{~nm}$ by the auto microplate reader.

\section{Statistical analysis}

Data were presented as mean $\pm \mathrm{SD}$ from at least three independent experiments and analyzed using Student's $t$-test. Statistical and graphic analyses were done using the software SPSS 19.0 (SPSS, Chicago) and Origin 8.0 (OriginLab Corporation). $P<0.05$ was defined as statistical significance.

\section{CONFLICTS OF INTEREST}

None to declare.

\section{GRANT SUPPORT}

This work was supported by the National Natural Science Foundation of China (Grants 81572184, 61527825and 81471699) and the Natural Science Foundation of Guangdong Province (Grant 2014A030313378) as well as the Fundamental Research Funds for the First Clinical Medicine College of Jinan University (Grant 2015108). 


\section{REFERENCES}

1. Siegel P, Moraca PP, Green JR. Sodium nitroprusside in the surgical treatment of cerebral aneurysms and arteriovenous malformations. Br J Anaesth. 1971; 43:790-795.

2. Arnold WP, Longnecker DE, Epstein RM. Photodegradation of sodium nitroprusside: biologic activity and cyanide release. Anesthesiology. 1984; 61:254-260.

3. Bates JN, Baker MT, Guerra R, Jr. and Harrison DG. Nitric oxide generation from nitroprusside by vascular tissue. Evidence that reduction of the nitroprusside anion and cyanide loss are required. Biochem Pharmacol. 1991; 42:S157-165.

4. Ignarro LJ. Biosynthesis and metabolism of endotheliumderived nitric oxide. Annu Rev Pharmacol Toxicol. 1990; 30:535-560.

5. Moncada S, Palmer RM, Higgs EA. Nitric oxide: physiology, pathophysiology, and pharmacology. Pharmacol Rev. 1991; 43:109-142.

6. Mellion BT, Ignarro LJ, Ohlstein EH, Pontecorvo EG, Hyman AL, Kadowitz PJ. Evidence for the inhibitory role of guanosine 3', 5'-monophosphate in ADP-induced human platelet aggregation in the presence of nitric oxide and related vasodilators. Blood. 1981; 57:946-955.

7. Stuehr DJ, Nathan CF. Nitric oxide. A macrophage product responsible for cytostasis and respiratory inhibition in tumor target cells. J Exp Med. 1989; 169:1543-1555.

8. Albina JE, Cui S, Mateo RB, Reichner JS. Nitric oxidemediated apoptosis in murine peritoneal macrophages. $\mathrm{J}$ Immunol. 1993; 150:5080-5085.

9. Moncada S, Erusalimsky JD. Opinion - Does nitric oxide modulate mitochondrial energy generation and apoptosis? Nat Rev Mol Cell Bio. 2002; 3:214-220.

10. Gonzalez R, Ferrin G, Aguilar-Melero P, Ranchal I, Linares CI, Bello RI, De la Mata M, Gogvadze V, Barcena JA, Alamo JM, Orrenius S, Padillo FJ, Zhivotovsky B, Muntane J. Targeting hepatoma using nitric oxide donor strategies. Antioxid Redox Signal. 2013; 18:491-506.

11. Fleming I, Busse R. Molecular mechanisms involved in the regulation of the endothelial nitric oxide synthase. Am J Physiol Regul Integr Comp Physiol. 2003; 284:R1-12.

12. Sandau K, Pfeilschifter J, Brune B. Nitric oxide and superoxide induced p53 and Bax accumulation during mesangial cell apoptosis. Kidney Int. 1997; 52:378-386.

13. Li J, Billiar TR, Talanian RV, Kim YM. Nitric oxide reversibly inhibits seven members of the caspase family via S-nitrosylation. Biochem Biophys Res Commun. 1997; 240:419-424.

14. Bal-Price A, Brown GC. Nitric-oxide-induced necrosis and apoptosis in $\mathrm{PC} 12$ cells mediated by mitochondria. J Neurochem. 2000; 75:1455-1464.

15. Pryor WA, Squadrito GL. The chemistry of peroxynitrite: a product from the reaction of nitric oxide with superoxide. Am J Physiol. 1995; 268:L699-722.

16. Calcerrada P, Peluffo G, Radi R. Nitric oxide-derived oxidants with a focus on peroxynitrite: molecular targets, cellular responses and therapeutic implications. Curr Pharm Des. 2011; 17:3905-3932.

17. Adams L, Franco MC, Estevez AG. Reactive nitrogen species in cellular signaling. Exp Biol Med (Maywood). 2015; 240:711-717.

18. Pacher P, Beckman JS, Liaudet L. Nitric oxide and peroxynitrite in health and disease. Physiol Rev. 2007; 87:315-424.

19. Blanco FJ, Ochs RL, Schwarz H, Lotz M. Chondrocyte apoptosis induced by nitric oxide. Am J Pathol. 1995; 146:75-85.

20. Heigold S, Sers C, Bechtel W, Ivanovas B, Schafer R, Bauer G. Nitric oxide mediates apoptosis induction selectively in transformed fibroblasts compared to nontransformed fibroblasts. Carcinogenesis. 2002; 23:929-941.

21. Boullerne AI, Nedelkoska L, Benjamins JA. Synergism of nitric oxide and iron in killing the transformed murine oligodendrocyte cell line N20.1. J Neurochem. 1999; 72:1050-1060.

22. Bernabe JC, Tejedo JR, Rincon P, Cahuana GM, Ramirez R, Sobrino F, Bedoya FJ. Sodium nitroprusside-induced mitochondrial apoptotic events in insulin-secreting RINm5F cells are associated with MAP kinases activation. Exp Cell Res. 2001; 269:222-229.

23. Quan YY, Qin GQ, Huang H, Liu YH, Wang XP, Chen TS. Dominant roles of Fenton reaction in sodium nitroprussideinduced chondrocyte apoptosis. Free Radic Biol Med. 2016; 94:135-144.

24. Cardaci S, Filomeni G, Rotilio G, Ciriolo MR. Reactive oxygen species mediate p53 activation and apoptosis induced by sodium nitroprusside in SH-SY5Y cells. Mol Pharmacol. 2008; 74:1234-1245.

25. Rauhala P, Khaldi A, Mohanakumar KP, Chiueh CC. Apparent role of hydroxyl radicals in oxidative brain injury induced by sodium nitroprusside. Free Radic Biol Med. 1998; 24:1065-1073.

26. Yamada M, Momose K, Richelson E, Yamada M. Sodium nitroprusside-induced apoptotic cellular death via production of hydrogen peroxide in murine neuroblastoma N1E-115 cells. J Pharmacol Toxicol Methods. 1996; 35:11-17.

27. Del Carlo M, Jr. and Loeser RF. Nitric oxide-mediated chondrocyte cell death requires the generation of additional reactive oxygen species. Arthritis Rheum. 2002; 46:394-403.

28. Nakagawa S, Arai Y, Mazda O, Kishida T, Takahashi KA, Sakao K, Saito M, Honjo K, Imanishi J, Kubo T. $\mathrm{N}$-acetylcysteine prevents nitric oxide-induced chondrocyte apoptosis and cartilage degeneration in an experimental model of osteoarthritis. J Orthop Res. 2010; 28:156-163.

29. Liang Q, Wang XP, Chen TS. Resveratrol protects rabbit articular chondrocyte against sodium nitroprusside-induced apoptosis via scavenging ROS. Apoptosis. 2014; 19:1354-1363.

30. Kurozumi R, Tokuzumi S, Kojima S. Does peroxynitrite involve in the elevation of cellular glutathione induced by sodium nitroprusside (SNP) in RAW 264.7 cells? Biological \& Pharmaceutical Bulletin. 2003; 26:1070-1075. 
31. Kurozumi R, Takahashi M, Kojima S. Involvement of mitochondrial peroxynitrite in nitric oxide-induced glutathione synthesis. Biol Pharm Bull. 2005; 28:779-785.

32. Lomonosova EE, Kirsch M, Rauen U and de Groot H. The critical role of Hepes in SIN-1 cytotoxicity, peroxynitrite versus hydrogen peroxide. Free Radic Biol Med. 1998; 24:522-528.

33. de Andres MC, Maneiro E, Martin MA, Arenas J, Blanco FJ. Nitric oxide compounds have different effects profiles on human articular chondrocyte metabolism. Arthritis Res Ther. 2013; 15:R115.

34. Turrens JF. Mitochondrial formation of reactive oxygen species. J Physiol. 2003; 552:335-344.

35. Beckman JS, Koppenol WH. Nitric oxide, superoxide, and peroxynitrite: the good, the bad, and ugly. Am J Physiol. 1996; 271:C1424-1437.

36. Nauser T, Koppenol WH. The rate constant of the reaction of superoxide with nitrogen monoxide: Approaching the diffusion limit. Journal of Physical Chemistry A. 2002; 106:4084-4086.

37. Radi R, Beckman JS, Bush KM, Freeman BA. Peroxynitrite oxidation of sulfhydryls. The cytotoxic potential of superoxide and nitric oxide. J Biol Chem. 1991; 266:4244-4250.

38. Goldstein S, Russo A, Samuni A. Reactions of PTIO and carboxy-PTIO with *NO, *NO2, and O2-*. J Biol Chem. 2003; 278:50949-50955.

39. Lin KT, Xue JY, Nomen M, Spur B, Wong PY. Peroxynitrite-induced apoptosis in HL-60 cells. J Biol Chem. 1995; 270:16487-16490.

40. Sandoval M, Zhang XJ, Liu X, Mannick EE, Clark DA, Miller MJ. Peroxynitrite-induced apoptosis in T84 and RAW 264.7 cells: attenuation by L-ascorbic acid. Free Radic Biol Med. 1997; 22:489-495.

41. Circu ML, Aw TY. Reactive oxygen species, cellular redox systems, and apoptosis. Free Radic Biol Med. 2010; 48:749-762.

42. Winterbourn CC, Metodiewa D. The reaction of superoxide with reduced glutathione. Arch Biochem Biophys. 1994; 314:284-290.

43. Winterbourn CC, Metodiewa D. Reactivity of biologically important thiol compounds with superoxide and hydrogen peroxide. Free Radic Biol Med. 1999; 27:322-328.

44. Jones CM, Lawrence A, Wardman P, Burkitt MJ. Kinetics of superoxide scavenging by glutathione: an evaluation of its role in the removal of mitochondrial superoxide. Biochem Soc Trans. 2003; 31:1337-1339.

45. Aruoma OI, Halliwell B, Hoey BM, Butler J. The antioxidant action of $\mathrm{N}$-acetylcysteine: its reaction with hydrogen peroxide, hydroxyl radical, superoxide, and hypochlorous acid. Free Radic Biol Med. 1989; 6:593-597.

46. Filomeni G, Aquilano K, Rotilio G, Ciriolo MR. Glutathione-related systems and modulation of extracellular signal-regulated kinases are involved in the resistance of
AGS adenocarcinoma gastric cells to diallyl disulfideinduced apoptosis. Cancer Res. 2005; 65:11735-11742.

47. Jamali B, Nakhjavani M, Hosseinzadeh L, Amidi S, Nikounezhad N, F HS. Intracellular GSH Alterations and Its Relationship to Level of Resistance following Exposure to Cisplatin in Cancer Cells. Iran J Pharm Res. 2015; 14:513-519.

48. Sies H. Glutathione and its role in cellular functions. Free Radic Biol Med. 1999; 27:916-921.

49. Wang YM, Peng SQ, Zhou Q, Wang MW, Yan $\mathrm{CH}$, Yang HY, Wang GQ. Depletion of intracellular glutathione mediates butenolide-induced cytotoxicity in HepG2 cells. Toxicol Lett. 2006; 164:231-238.

50. Perkins A, Nelson KJ, Parsonage D, Poole LB, Karplus PA. Peroxiredoxins: guardians against oxidative stress and modulators of peroxide signaling. Trends Biochem Sci. 2015; 40:435-445.

51. Ferrer-Sueta G, Radi R. Chemical biology of peroxynitrite: kinetics, diffusion, and radicals. ACS Chem Biol. 2009; 4:161-177.

52. Trujillo M, Clippe A, Manta B, Ferrer-Sueta G, Smeets A, Declercq JP, Knoops B, Radi R. Pre-steady state kinetic characterization of human peroxiredoxin 5: taking advantage of Trp84 fluorescence increase upon oxidation. Arch Biochem Biophys. 2007; 467:95-106.

53. Manta B, Hugo M, Ortiz C, Ferrer-Sueta G, Trujillo M, Denicola A. The peroxidase and peroxynitrite reductase activity of human erythrocyte peroxiredoxin 2. Arch Biochem Biophys. 2009; 484:146-154.

54. Radi R. Peroxynitrite, a stealthy biological oxidant. J Biol Chem. 2013; 288:26464-26472.

55. Immenschuh S, Baumgart-Vogt E. Peroxiredoxins, oxidative stress, and cell proliferation. Antioxid Redox Signal. 2005; 7:768-777.

56. Radi R, Beckman JS, Bush KM, Freeman BA. Peroxynitrite-induced membrane lipid peroxidation: the cytotoxic potential of superoxide and nitric oxide. Arch Biochem Biophys. 1991; 288:481-487.

57. Bartesaghi S, Trujillo M, Denicola A, Folkes L, Wardman P, Radi R. Reactions of desferrioxamine with peroxynitritederived carbonate and nitrogen dioxide radicals. Free Radic Biol Med. 2004; 36:471-483.

58. Parvar M, Mehrzad J, Chaichi MJ, Hosseinkhani S, Golchoubian H. Quenching effect of deferoxamine on free radical-mediated photon production in luminol and orthophenanthroline-dependent chemiluminescence. Chinese Chemical Letters. 2014; 25:630-634.

59. Ottaviani E, Barbieri D, Malagoli D, Franchini A. Nitric oxide induces apoptosis in the fat body cell line IPLB-LdFB from the insect Lymantria dispar. Comp Biochem Physiol B Biochem Mol Biol. 2001; 128:247-254.

60. Oury TD, Piantadosi CA, Crapo JD. Cold-induced brain edema in mice. Involvement of extracellular superoxide dismutase and nitric oxide. J Biol Chem. 1993; 268:15394-15398. 